\title{
Figurations of the Future
}

On the Form and Temporality of Protests among Left Radical Activists in Europe

Krøijer, Stine

Published in:

In the Event

Publication date:

2015

Document version

Peer reviewed version

Citation for published version (APA):

Krøijer, S. (2015). Figurations of the Future: On the Form and Temporality of Protests among Left Radical Activists in Europe. In L. Meinert, \& B. Kapferer (Eds.), In the Event: toward an Anthropology of Generic Moments Berghahn Books. http://www.berghahnbooks.com/title.php?rowtag=Meinertln 
Figurations of the Future:

\title{
On the Form and Temporality of Protests among Left Radical Activists in Europe
}

\section{Stine Krøijer}

\section{Biographical Data}

Stine Krøijer is Assistant Professor at the Department of Anthropology, Copenhagen University. Her new book on left radical activism Figurations of the Future is forthcoming in 2014 (Berghahn Books). She has co-edited Social Analysis vol. 55(2) taking a fresh look at the anthropology in and of Scandinavia. Currently she is working on a new research project called 'the political life of trees,' which focuses on human interaction with trees in the Ecuadorian Amazon and among environmental activists, and the forms of politics and political potentiality emerging from this interaction.

\section{Contact Information}

Department of Anthropology

University of Copenhagen

Øster Farimagsgade 5, opgang I

DK-1353 Copenhagen $\mathrm{K}$

Phone: 4535323464

stine.kroijer@anthro.ku.dk

\begin{abstract}
During the past ten years, protests timed to coincide with international summits have become a recurrent phenomenon in Europe. The present article describes the protests of left radical activists during NATO's sixtieth anniversary summit in Strasbourg in 2009, paying attention to the particular relationship between form, body and time. The article establishes a dialogue between the Manchester School and the performative theory of Victor Turner, Viveros de Castro's theorization of Amerindian perspectivism and newer theories of time and the body. The article argues that during confrontations between activists and the police a moment of bodily intensity arises, which entail a work on time. The skilful performance makes a temporal bodily perspective appear that overcomes the antinomies between immanence and
\end{abstract}


transcendence, between the present and the future, that characterize much thought on social change.

Key words: Performance, activism, anarchism, NATO, time, body, affect, event

\section{Introduction}

The present article analyses the relationship between what we conventionally think of as the present and the future in the context of a protest event during NATO's sixtieth anniversary summit in Strasbourg in 2009. During the rally a compressed body of protesters emerged in a situation in which approximately three hundred left radical activists[1] were 'kettled,' police jargon for the temporary confinement of protestors at a demonstration, on a bridge near the French-German border. The situation reveals how the body becomes a site of qualitative transformation that I conceptualize as a bodily figuration of the future.

During the past decade, Europe has been the scene of recurrent protests against the global economic and political elite at World Bank, European Union, NATO and G8/G20 summits. These summits are well-planned and tightly scheduled events when it comes to official summit participants and organisers, the police, as well as protesters appearing on the streets to call attention to the injustices committed in the name of civilization and progress. In this sense, summit events - and the protests in particular - have much in common with elaborate performative rituals (Juris 2008; cf. Turner 1982, 1987). During the protests different techniques, such as masks, colours, music, and performative styles, are employed to engage participants and to engender particular effects among participants and audiences (see Mitchell 2006). I therefore think of performances as acts in themselves that organize time and space, that is, activist's temporal incarnations of another future.

In describing events during a day of protests - and particularly the moment of bodily and violent confrontation between activists and the police at the Grand Pont near the Europe Bridge connecting France and Germany - I have been inspired by the situational analysis of the Manchester School and their acute attention to conflict and change (Gluckman 1958 [1940]; Van Velsen 1967). Victor Turner's work on rituals and performances is of particular relevance here. Turner (1982: 29-32) developed an anthropological concept of performance through his attention to liminoid phenomena in 'modern' societies while simultaneously preserving a dialogue with classical 
studies of ritual and liminality (see also Mitchell 2006: 384; Sjørslev 2007: 15-16). In earlier work, Turner $(1967,1968)$ had stressed the integrative function of ritual in agreement with Gluckman, and in so doing he also reproduced Emile Durkheim's basic thesis about the function of symbols in rituals, namely that rituals first and foremost reaffirm the sentiments upon which a group is based (Durkheim 1954 [1912]: 216).[2] Turner epitomized this notion in the concept of communitas (1982: 44). Yet later, he came to highlight the transformative and potential quality of the liminal or liminoid phase in rituals and social drama that, as he put it, "can generate and store a plurality of alternative models for living, from utopias to programs" (ibid.: 33; cf. Kapferer 2006: 137). Turner's allusion to the existence of other such immanent models or worlds that may appear during a ritual or performance goes to the heart of what is also at stake here.

I preserve the concept of performance, and the particular attention to form it entails, but in approaching the protest event, I aim at stripping it of its Durkheimian constructivist legacy in order to draw attention instead to the effects of the protest event (see Kapferer 2005). What interests me with regard to the collective body in the 'kettle' is not communitas or affective solidarity, but synchronicity and bodily affect (Massumi 2002). In attending to the synchronicity of the compressed body/ies, I seek to dissolve the linear ontology of time underlying the ritual process, even in Turner's version, by pointing to the body's indeterminacy and openness to an otherwise in the here-and-now. In the following, I shall explore the dynamic at the bridge in Strasbourg, a situation which forms part of a two-year period fieldwork (2007-2009) among left radical activists in northern Europe.

\section{Kettled in Strasbourg}

The atmosphere is tense at the evening spokes council meeting[3] after the morning's confrontations with the police at the entrance to the protest camp. The clashes got underway after a group of demonstrators left the camp, which is located six kilometres south of the center of Strasbourg, to protest against the killing of a participant at the London G20 summit a few days earlier. Barricades have been built in the street and set on fire by activists, who have all changed into black clothes and covered their faces with hoods or bandanas, while the approaching police have been met by several more or less coordinated waves of stones and bottles. 
The meeting is supposed to discuss the organization of a 'black bloc'[4] in conjunction with the large demonstration organised by the European Peace movement the following day, but now the idea of a 'diversity of tactics' is put to the test. Half a year earlier, visiting activists from all over Europe had hammered out an action concept at a secret meeting during which it was agreed to respect all tactical preferences and avoid public condemnation of other groups in the context of the protests that are due to start tomorrow. Now, hundreds of people have crowded into the large red and blue circus tent used for meetings in the camp, activists sit on stacks of hay on the ground, and the tent buzzes with the urge to discuss the day's events.

Alvin from the Block NATO coalition, organising a civil disobedience action to blockade the access roads to the summit venue, speaks first. He informs the assembled that the police plan to seal off the whole inner city, and he argues that people wanting to take part in the blockade the following morning should leave within a few hours and try to sleep somewhere in the city's center. Another option would be to walk to the city in smaller groups in the early hours of the morning. He also urges people not to get into a confrontation with the police the following day.

Several activists around me are visibly bothered, including two of my key interlocutors, Natalie and Nicola, whom I have followed for the past month in their preparations for the protests, and Alvin's words are clearly lost on the gathering. Before entering the tent, Natalie has told me that there will be riots. In her view, people are "pissed off" due to the violent death of the protester in London, by the fact that their protest in Strasbourg is being relegated to an industrial zone outside the city's center, and because approximately 5,000 protesters have been held at the French-German border and denied entrance into France. For days there have been whispers about 'alternative targets'. Natalie interrupts Alvin by shouting, "That's all very fine, but the police have informed us that they will not let us leave the camp until 11 a.m. when the summit has already started." I never find out if this is actually true, or whether it is just one of the many rumours that have been circulating all week. Nicola, a young architect and a member of the French Anarchist Federation, who is sitting next to me in the hay, whispers, "I love this. Now you have to think for yourself."

Those who want to participate in the black bloc decide to leave in the early hours of the morning. I am inclined to follow them, but I am concerned about my own safety and that of four students whom I have taken along to make a study of the 
construction of the camp and its imaginary effects. Outside the tent, people are having talks in smaller groups. Military helicopters have been circling over our heads for days, and some activists are worried that the police might finally decide to raid the camp during the night. Nicola and I decide to drive my students and a group from Revolt France, who will act as street medics the following day, into the city's center in his car. We agree that we can probably find a place to have a few hours rest at Molodoi, a self-managed social center that also serves as a point of convergence during the summit. We grope around for our sleeping bags and a few other personal belongings in the dark, and finally take off to find a Nicola's car. Before leaving, Nicola remembers to remove a metal truncheon from his trunk in a hide it in nearby shrubbery.

The streets of Strasbourg lie dark and empty. Since yesterday, they have been deserted. Shops, schools and other institutions have been closed, and all public transportation has been cancelled. Special summit passes have been issued for the local inhabitants, allowing them to move to and from their homes. The first trip into the city goes well, but on our second trip from the camp we start getting nervous. We have a creeping feeling that we are being followed, although we tell each other that we have done nothing wrong. Police officers are posted on the street corners, and in a moment of absent-mindedness, Nicola drives the wrong way down a one-way street. We are pulled over. The police search the car, the trunk and us. In the trunk they find Nicola's helmet, skater safety gear and his notebook. The highest-ranking officer starts turning over its pages with a display of great interest: "So, you are an organizer," he says to Nicola. Nicola denies it, but is taken into custody. The rest of us are left on the street, and we walk to Molodoi while my notebook burns in my pocket. Luckily, Nicola and I remembered to exchange personal data before we left the camp, and after waiting anxiously for an hour and a half, I call up the legal team[5] to inform them of Nicola's arrest. An hour later he is back. He says that he is "okey" except for having "his head screwed up by all their questions." We drink tea before tiptoeing into the upstairs room where sleeping activists cover every inch of the floor.

We get up before 7 a.m., and quickly head to the meeting point for the blockade. We walk along the quays surrounding Strasbourg's inner city, which is also the perimeter of the 'red zone' that is off-limit to protesters. We observe the police who have taken guard on the bridges. When we reach the Quai des Alpes we see the 
first groups of the black bloc arriving from the camp. Tear gas already fills the air, and clashes with the police get underway as the groups try to find a crossing point. We watch in silence for a while and then decide to move on. We head north and pass the official meeting point of the blockade, which has already been abandoned. We turn west towards the center following the tail of the 'pink bloc' and the scent of tear gas until we reach the blockade at the intersection of Avenue des Vosges and Avenue de la Paix. We are stopped and searched repeatedly. These measures should allow the police to identify the 'unwanted elements' moving through the public space, and everybody walking the street has to undergo repeated identity checks and bag searches.

The pink bloc is a colourful gathering mainly organized around a large samba band. The men and women typically dress in pink, have elaborate hairdos and hats, and engage in street dancing and drum beating. There is also a contingent of German clowns, each wearing a hilarious mix of army and clown costumes. They march and drill in front of the police line mimicking the officers' movements, which adds an element of comic suspense to the situation. The police watch with their visors up, but only half an hour earlier they had tried to chase the pink bloc protesters from the street. The participants had inhaled some teargas in the effort to reach and hold the blockade, but whether they have prevented the delegates to the NATO summit from reaching the conference center at the Palais de la Musique et des Congrés in time is still uncertain.

We take turns dancing and resting, and Nicola attends to a few people who are feeling queasy from the tear gas. Much to my surprise, I run into both Swedes and Greeks whom I had previously met during the 2008 Social Forum in Malmö, and as the situation has calmed down we have time for a chat. Alvin announces that the summit has been delayed for an hour due to the blockade, but my Greek companion seriously doubts this. "The blockade has not been sufficiently effective," he says; "there are plenty of places to get through. The delay was probably only caused by Berlusconi going to the rest room." In light of the peaceful attitude of the police, it is clear that we no longer pose a threat to the smooth running of the official summit, so at a spokes council meeting following Alvin's announcement it is decided to pull up stakes and head towards the large demonstration organised by the European Peace Movement (which also including a black bloc) that is due to start within the hour. 
First, however, Nicola and I need to prepare to join the confrontations in the harbour area close to the French-German border. We make a detour back to Molodoi to stock up on medical supplies. When we leave, our bags are stuffed with bandaging, cotton wool for broken noses, a few medicines, and six or seven bottles of Maalox, a wonder treatment for heartburn and tear gas. We are both eager to return to the action, and I try to ignore my growing fatigue due to lack of sleep. From a distance we see black smoke rising from the Bridge of Europe, normally the busiest border between France and Germany. Close by, the NATO leaders took part in 'a diplomatic footstep" - that is an official photo session - a few hours earlier, and now the border post has been set on fire by protesters. Nicola is wearing an old bike helmet and skater safety gear. It is a warm day and he looks at me smiling. "The border is burning," he says. "Let's go to war."

We follow the directions of the smoke and the sound of the helicopters until we reach Grand Pont, a long bridge connecting the inner city with the harbour area, which is about $1.5 \mathrm{~km}$. from the burning border post. On the way to the bridge, we are stopped repeatedly by police officers searching our bags and questioning us about our whereabouts, intentions, and organisational affiliation. As we reach Grand Pont, large water cannons and a dozen police vans take up positions in the middle of the bridge. Cement blocks covered with plastic and barbed wire have been placed across the street. Nicola approaches a police officer and asks to be let through in order to provide medical aid to some of the activists on the other side. In a polite but firm voice, the officer informs us that it will not be possible.

At the foot of the bridge we meet up again with some 300 activists from the pink bloc, who had all participated in the failed attempt to blockade the NATO summit venue. Some people are taking a rest or looking for food and water, while others are eager to cross the bridge, either to join a large demonstration convened by the European Peace Movement or to participate in clashes with the police, which have been underway since 7 a.m. that morning. A row of police cars leaves the bridge, and after a spokes council meeting, the assembled protestors decide to make an attempt to 'open' the bridge.

As we walk up the bridge, three rows of riot police, protected by anti-riot helmets and shields and tactical knee, arm and chest pads, obstruct our retreat. For a minute I consider jumping down the steep slope on the side of the bridge to avoid what seems to be an imminent arrest, but I am discouraged by the way a couple of 
protesters are severely beaten and kicked back into the group when they try and make an escape. The police line moves forward quickly and, aided by portable fences, pushes the samba band and everybody else ahead while the drummers struggle to keep time. We are squeezed together in what I later learn is called a 'kettle' - police jargon for the temporary confining of protestors. The scent of tear gas reaches us from the other side of the bridge, where around a thousand activists are hurling stones at the police. In our kettle on the bridge, the samba band keeps on playing against a background of silence. The refrain, 'This is what democracy looks like!' is shouted repeatedly. When it was shouted at the blockade in the morning, I thought it referred to our control of the street, but now it sounded more like a reference to police repression. I talk briefly to Svante, another familiar face from the European Social Forum in Malmö and member of a Swedish anti-militarist group. He explains that he had slept under a bridge that night in order to participate in the blockade. His affinity group had been planning to head back to the camp. "Now we don't know how it will end up, " he says with a pale smile.

We are compressed further, and the temperature rises in the kettle. People raise their hands to show their peaceful intentions. I become acutely aware that if someone panics or loses her or his temper, the situation may turn into violent confrontation, resulting in mass arrest. When the first line is pressed back by the police, it instantly produces a collective wave that rolls back and forth, with the rhythmic drumming of the samba band giving us a shared pulse. We have become one body acting together: a movement in one part instantly exerts an influence on the rest. I am filled with a strong sense of strength and solidarity, mixed with fear. Nobody moves or talks. The air is full of a vibrant tension, and I observe the jaw muscle of the nearest police officer turning white as he fixes his gaze somewhere above my head. I wonder what kind of being is hiding beneath the armour. It is a long, terrifying moment of possibility in which I mostly feel our own collective breathing.

After some 15 minutes, the riot police withdraw without a word, and we are allowed to walk away. People start talking again. We hug and laugh, and some people even start dancing in the street. When I question him, Nicola explains that he has a mixed feeling of relief and power. Around us people are laughing, and I share the outburst of joy. The elation is tinged with anger and a rare sense of strength, which appears rather odd, given that we did not have the upper hand in the situation. I observe the large water cannons pulling away. Someone pops open a red fire hydrant 
to allow everybody a sip of water. The water pours out on to the warm asphalt, and Svante, who stood next to me in the kettle, remarks how happy he is that we were able to "keep calm and control the situation." A middle-aged German man joins in to tell us that he had spent several hours in his car the same morning to reach the protest and now "had experienced what he came for." He rambles on, but I turn away to find out what our next move will be.

After the moment of joyful celebration, we hold another spokes council meeting at Rue du Grand Pont. About half the group, including half the samba band, decide to return to the camp, while the rest of us want to proceed to the remainder of the demonstration-cum-riot. Several clowns from the pink bloc remove their makeup and costumes. The next day, while driving me to the railway station, one of the clowns from Freiburg explains: "I lost the clown in the kettle. I used to run as the black bloc, but started clowning about four years ago. Clowning is a good way to go into a confrontation, I think. But I got so angry [in the kettle] that I could not continue clowning and handle the situation in a humorous manner. After all the tension, I just felt angry and had to take off the clown."

In the otherwise deserted harbour area, the demonstration has fallen apart, and people drift around aimlessly. Simultaneously, the violent clash between militant protesters, joined by youngsters from the banlieues, [6] and the riot police continue near the Bridge of Europe. The confrontation takes place at a distance and follows a slow pace. Small, dispersed groups of activists take turns throwing stones and Molotov cocktails at police officers on foot, who keep their distance and respond with tear gas, concussion grenades and eventually a few stones. The activists are ritually clothed in black, with gas masks, helmets and padding in striking similarity to the police. Even their bodily movements when attacking and hiding behind their shields are similar - coordinated yet without central coordination, as is, I think, the idea about the need 'to take action' to change the course of events.

At the Bridge of Europe, activists have set fire to the border post and a nearby Ibis hotel. Two participants explain that the police have been stationed here, while others seem to think that it has been used for rejected asylum-seekers. In either case, the target is considered legitimate. One of my student assistants, who did not wish to take part in the blockade, had been present at the bridge by mistake, and in the evening she describes how small groups of youngsters ran around the burning buildings, shouting with joy and giving each other the thumbs up. Locals from the 
nearby banlieue joined in, she explained, plundering a couple of smashed-up gas stations. The black bloc riots and the property destruction are the incidents that will be reported in the mainstream media during the days that follows. "No Borders," reads the graffiti scrawled on the burned out border control post.

In the late afternoon, people start walking back towards the camp, while others change their clothes to appear like 'regular citizens,' which might allow them to pass through the police checkpoints into the city's center. Nicola, myself, and a few other people walk towards the center, but to reach Molodoi and Nicola's car we have to pass over one of the bridges, which the police are still heavily guarding. We are repeatedly turned away, although we try to appear as inoffensive as possible. "Try not looking them in the eyes," Nicola advises. I remember thinking that there is apparently no agreement between the activists and the police about when the party is over. I have trouble walking due to large blisters on both my feet, and we are all soon overwhelmed by fatigue. At the fourth bridge, we change our tactic. One of my female student assistants and I walk up the bridge first; we approach the police directly and kindly ask them to let us through. They check our passports and question Nicola, but it works. Once we are well on the other side, Nicola mumbles, "So, they are humans after all. I told him [the police officer] that I was tired, and he said that he was too.”

When we are back in the car, Nicola describes the day as a great success: "You can't expect that we can accomplish everything in one day," he says, "but we managed to control the street and to create disorder in their planning." "What do you mean by everything?" I ask. "Well, you know, that the revolution doesn't come in one day," Nicola replies. We continue in silence, lost in our own thoughts. Later in the evening in Molodoi, while we are eating and waiting for some transport back to the camp, Nicola rests his forehead on the table top and starts to cry. "I was just not strong enough," he repeats. I am overwhelmed by a deep sadness that will follow me for weeks, without being able to pinpoint the reason why.

\section{Bodily affect and becoming otherwise}

The situation that I have described poses more questions than I will be able to answer here, but the moment at the bridge begs further analysis. What was the nature of the compressed body of protesters on the bridge? How did the activists come to associate 
strength and control with a situation in which the police clearly have the upper hand? What is the relationship between body and time as revealed by this incident?

There is little doubt that the actions and engaging in bodily confrontation with the police give rise to what we usually think of as strong emotions. I have described how being kettled in Strasbourg evoked not only anxiety and even fear, but also a sense of mutual solidarity, control and strength. An obvious model for understanding these emotions is that of the ritual process, as people close to the movement have argued (Jordan 2002; Juris 2008). In this vein, protests, and particularly the moment of confrontation, can be associated with the liminal or liminoid phase of rituals. According to Turner (1982), it is characteristic of this phase that strong feelings are evoked.[7] Yet, I am reluctant to understand the ritual, and thus the protests, as a social construction of personal feelings, as argued in much anthropology of emotions (Lutz and White 1986; Wulff 2007). Rather, what seems at stake here has to do with the intensity and synchronicity of the body/ies at the bridge.

I have described the physical compression of protesters at the bridge in Strasbourg as a collective body with joint breathing, with the movement of one part instantly impinging on the rest and the rhythm of the samba band becoming the collective pulse. In my view, the compression and intensity of the situation gave rise to a bodily synchronicity, that is, a bodily belonging to the same time.

The experience of becoming a synchronic body occurs frequent at protests, but itmay take a variety of forms, as when activists walk in tight rows with their arms locked together during a demonstration. Dressed in similar black clothes, they thereby become indiscernible from one another. Becoming a synchronic body can also occur when free-form actions, such as the riots in Strasbourg, obtain a swarming effect, which implies a synchronicity between dispersed elements. An outside force may produce a similar effect: the emergence of a synchronic body often seems to arise in situations in which bodies are confined in narrow spaces or become physically compressed. This was particularly salient when several hundred activists were kettled by the police at the bridge in Strasbourg.

In the notes to his translation of A Thousand Plateaus, Massumi offers a Deleuzian concept of affect. He argues that affect is "prepersonal intensity corresponding to the passage from one experiential state of the body to another and implying an augmentation or diminution of the body's capacity to act" (Massumi in Deleuze and Guattari 1987: xvii). Hence, affect is an experience of intensity, a 
moment of unformed potentiality that cannot be captured in language (Massumi 2002: 30). In my view, this can enable us to grasp the contradiction between immobility experienced in the kettle and the increased sense of power and strength. The moment at the bridge entailed a change in the experiential state of the body; simultaneously, it was a change in bodily form and state of vitality. The body of protesters temporally becomes the source of what Deleuze and Guattari has called an otherwise in the plane of immanence (see Deleuze and Guattari 1987: 266-67). I think of these eventful moments as a state of active time where some of the ideals that activists struggle for temporarily become real and concrete, a bodily otherwise, in the here and now of the confrontation.

These moments of active time that correspond to the emergence of a synchronic body can be contrasted with several other moments in the case above, namely, when we had the experience of being followed and watched by the police during our nightly drive, when Nicola was taken into custody, and when he cried from his lack of strength to face up to the situation. In these situations, in which activists are singled out and individualized, they describe themselves as overwhelmed by sadness, resignation and paranoia. In sum, the life of an activist oscillates between various temporal modes of being, namely between active time and dead time, both of which hinge on the body (Krøijer forthcoming, Krøijer 2014).

Active time is prevalent in situations, such as the one at the Strasbourg bridge, when activists come to exist in a state of differentiated or precipitated synchrony. In this context, what we think of as experiences of solidarity, horizontality, strength, and freedom are embedded within this precipitated time. In the case of street protests, it is the bodily confrontation between activists and the police (in its various forms) that both elicit the conflicts surrounding NATOs warfare, and works as the point of transition between active time and dead time.

I think of these as different bodily perspectives along the lines suggested by Viveiros de Castro (Viveiros de Castro 1998, 2004). In his work on Amerindian cosmology, Viveiros de Castro redefines the categories of nature and culture and criticises the use of Western naturalism, which is founded on the idea of a shared nature and multiple cultures, to describe non-Western cosmologies. Based on his study of the way humans, animals and spirits see each other among the Arawete in Brazil, Viveiros de Castro (1998) argues that all these categories share an anthropomorphic essence (culture), but that they show themselves in different 
'clothes', that is, different bodily appearances (natures). Thus, Western multiculturalism is replaced with Amazonian multinaturalism, implying a spiritual unity and a corporal diversity. The result is a cosmology of multiple bodily viewpoints. The existence of multiple points of view does not mean that the same world is being apprehended from different angles, but "that all beings see the world the same way - what changes is the world they see" (ibid.: 477).

Obviously, an European activist cosmology is different from that of indigenous Amazonians, but the bodily ability to take a certain point of view is analogous. It is the body that makes the difference. If we transpose Amazonian multinaturalism to Western thinking about time, it should be possible to reconsider the antinomy between the present and the future, between immanence and transcendence, which is inherent in much thinking about social change. It is often taken for granted that the ontology of time is a linear and fluid, that it is a single, shared 'clock time', which we may in turn perceive differently (Hodges 2008; Gell 1992). Turner's ritual model suffers from a linear ontology of time that describes the ritual as a unified and linear process around which order and disorder, rule and exception, the everyday and the festive are temporally reversed. In this light, I find it unsuitable for grasping the multiple ontologies of time that intersect during a protest event.

In the present context, it is the skilful performance that makes the temporal bodily perspective appear. This capacity to move between different temporal perspectives - namely dead time and active time - depends, for example, on the ability of protestors to take a certain bodily point of view during confrontations with the police. In the case of the kettle, the compressed body/ies is/are put together as one composite entity and become, in the words of Viveiros de Castro (1998: 482), "the site of a differentiating perspective."

\section{Figuration of the future}

In this article, I have argued that a skilful protest performance has an effect on time. I have found that paying attention to the body and the question of time in confrontations between left radical activists and the police is decisive for understanding the form that political actions take among left radical activists. The bodily confrontation is key here because it has an effect on time: it is the body that splits time when it is confronted with an obstacle (in this instance the police). 
However, the compressed, synchronic body can be characterised neither as entirely immanent, nor as a perfectly transcendent force. In this context the materiality of the body matters.[8] Through the study of these intensified moments of potentiality, or quasi-events, in the shadow of the formal summit event, I have shown how the body engenders time (cf. Povinelli 2010). The confrontation implies not multiple epistemologies of time, but various temporal perspectives, which is what I call figuration of the future. The synchronic body of protestors, in other words, is a figuration of the future, one that stands in a simultaneous relationship to the present and the future by materializing the otherwise in the here and now. This figuration is not a pre-figuration, that is, anticipation or foreshadowing of a future to come (cf. Maeckelbergh 2009), but a giving of bodily form to the indeterminable.

In sum, what my ethnography suggests is that time is not one flow from the past through the present to the future, but that it is non-chronological and that multiple times are simultaneous or co-existent (see Foucault 1986: 24-6; Tonkin 1992: 72-5; Hodges 2008: 409).[9] Like the different natures that shamans and spirits may assume in Amazonian societies, activists can acquire different temporal perspectives by way of bodily alterity. To the new generation on the extraparliamentarian left change is not a linear process of revolutionary transformation (similar to the perception of change among Gluckman and his collegues). What we conventionally think of as the future is not bound to the present (as a process) nor is it to be extrapolated from it; rather, it exists only as a kind of latent active time (cf. Grosz 2005: 110; Miyazaki 2004: 70) in the body. In the present context, it is the performative confrontation that makes the future appear.

\section{References}

Deleuze, Gilles and Félix Guattari.1987. A Thousand Plateaus: Capitalism and Schizophrenia. Minneapolis and London: University of Minnesota Press.

Durkheim, Emilie. [1912] 1954. The Elementary Forms of Religious Life. New York: Free Press.

Foucault, Michel. 1986. Of Other Spaces. Diacritics 16: 22-37.

Gell, Alfred. 1992. The Anthropology of Time: Cultural Constructions of Temporal Maps and Images. Oxford: Berg. 
Gluckman, Max. [1940] 1958. Analysis of a Social Situation in Modern Zululand.

Manchester: Manchester University Press for the Rhodes-Livingstone Institute.

Graeber, David. 2002. The New Anarchists. New Left Review 13: 61-73.

Graeber, David. 2009. Direct Action: An Ethnography. Edinburgh: AK Press.

Grosz, Elisabeth. 2005. Time Travels: Feminism, Nature, Power. Durham, NC: Duke University Press.

Hodges, Matt. 2008. Rethinking Time's Arrow: Bergson, Deleuze and the Anthropology of Time. Anthropological Theory 8 (4): 399-429.

Jordan, John. 2002. The Art of Necessity: The Subversive Imagination of Anti-Road Protest and Reclaim the Streets. Pp. 347-357 in: The Cultural Resistance Reader, ed. Stephen Duncombe. London: Verso.

Juris, Jeffrey S. 2008. Networking Futures: The Movement against Corporate Globalization. Durham, NC: Duke University Press.

Kapferer, Bruce. 2005. Sorcery and the Beautiful: A Discourse on the Aesthetic of Ritual. Pp. 129-160 in Aesthetics in Performance: Formations of Symbolic Construction and Experience, eds. Angela Hobart and Bruce Kapferer. New York: Berghahn Books.

Kapferer, Bruce. 2006. Situations, Crisis and the Anthropology of the Concrete: The Contribution of Max Gluckman. Pp. 118-155 in The Manchester School: Practice and Ethnographic Praxis in Anthropology, eds. T. M. S. Evens and Don Handelman. New York: Berghahn Books.

Katsiaficas, George. 2006. The Subversion of Politics: European Autonomous Social Movements and the Decolonization of Everyday Life. Oakland, CA: AK Press.

Krøijer, Stine and Inger Sjørslev. 2011. Autonomy and the Spaciousness of the Social: The Conflict between Ungdomshuset and Faderhuset in Denmark. Social Analysis 55 (2): 84-105.

Krøijer, Stine. 2014. Aske's Dead Time: An Exploration of the Qualities of Time among Left Radical Activists in Denmark. Pp. 57-80 in Ethnographies of Youth and Temporality: Time Objectified, eds. A. L. Dalsgård, et. al. Philadelphia: Temple University Press.

Krøijer, Stine. Forthcoming. Figurations of the Future: Forms and Temporalities of Left Radical Politics in Northern Europe. Oxford: Berghahn Books.

Lock, Margaret. 1993. Cultivating the Body: Anthropology and Epistemologies of Bodily Practice and Knowledge. Annual Review of Anthropology 22: 133-55.

Lutz, Catherine, and Geoffrey White. 1986. The Anthropology of Emotions. Annual Review of Anthropology 15: 405-36.

Maeckelbergh, Marianne. 2009. The Will of the Many: How the Alterglobalization Movement is Changing the Face of Democracy. New York: Pluto Press.

Massumi, Brian.2002. Parables for the Virtual. Durham and London: Duke University Press.

Mauss, Marcel. [1934] 1992. Techniques of the Body. In Incorporations, Zone (Series), 6, edited by J. C. and S. Kwinter. New York: Zone. 
Mitchell, Jon P. 2006. Performance. Pp. 384-401 in Handbook of Material Culture, eds.Chris Tilley, Susanne Küchler, Mike Rowlands and Patricia Spyer. London: Sage.

Miyazaki, Hirokazu. 2004. The Method of Hope: Anthropology, Philosophy, and Fijan Knowledge. Stanford, CA: Stanford University Press.

Povinelli, Elizabeth. 2006. The Empire of Love: Toward a Theory of Intimacy, Genealogy, and Carnality. Durham, NC: Duke University Press.

Sjørslev, Inger. 2007. Ritual, performance og socialitet: En introduktion. Pp. 9-23 in: Scener for samvar: Ritualer, performance og socialitet, ed. Inger Sjørslev. Aarhus: Aarhus Universitetsforlag.

Povinelli, Elizabeth. 2010. Economies of Abandonment: Social Belonging and Endurance in Late Liberalism. Durham, NC: Duke University Press.

Tonkin, Elizabeth. 1992. Narrating Our Pasts: The Social Construction of Oral History. Cambridge: Cambridge University Press.

Turner, Victor. 1967. The Forest of Symbols: Aspects of Ndembu Ritual. Ithaca, NY: Cornell University Press.

Turner, Victor. 1968. Schism and Continuity in an African Society. Manchester: Manchester University Press.

Turner, Victor. 1982. From Ritual to Theatre: The Human Seriousness of Play. New York: PAJ Publications.

Turner, Victor. 1987. The Anthropology of Performance. New York: PAJ Publications.

van Velsen, Jaap. 1967. The Extended Case Method and Situational Analysis. Pp 129-149 in: The Craft of Social Anthropology, ed. A. L. Epstein. London: Tavistock.

Vilaça, Aparecida. 2005. Chronically Unstable Bodies: Reflections on Amazonian Corporalities. Journal of the Royal Anthropological Institute 11(3): 445-464.

Viveiros de Castro, Eduardo. 1998. Cosmological Deixis and Amerindian Perspectivism. Journal of the Royal Anthropological Institute 4(3): 469-488.

Viveiros de Castro, Eduardo. 2004. Exchanging Perspectives: The Transformation of Objects into Subjects in Amerindian Ontologies. Common Knowledge 10(3): 463-484.

Wolputte, Steven Van. 2004. Hang on to Your Self: Of Bodies, Embodiment and Selves. Annual Review of Anthropology 33: 251-269.

Wulff, Helena. 2007. Introduction: The Cultural Study of Emotions, Mood and Meaning. Pp. 1-18 in: The Emotions: A Cultural Reader, ed. Helena Wulff. Oxford: Berg Publishers.

\section{Notes}


[1] 'Left radical activists' is an umbrella term used by activists in Northern Europe to denote people of an anarchist, autonomist and syndicalist bent. The term largely covers groups that can also be identified as the radical strain of the global justice movement (Graeber 2009; Maeckelbergh 2009).

[2] Turner (1982: 20) characterized his work as 'comparative symbology', which refers to the interpretation of symbols, but also to the study of expressions by means of symbols. Turner had earlier adopted a processual view of the rite of passage from Arnold van Gennep, which stated that the ritual process was divided into three phases: separation, transition (a state of social limbo out of secular time that generates a strong sense of communitas among the participants) and reincorporation (ibid.: 24; see also Turner 1987: 34). Focusing explicitly on the forms of religious life, Durkheim ([1912] 1954) asserted that the true function of the rites performed by Australian clans was not, as they themselves understood it, to increase their totem species but to produce socially useful effects. According to Durkheim, during the rite the Australians experience a strong enthusiasm and as a consequence are "transported to another level of reality," which make them feel outside and above normal moral life (ibid.: 216, 226).

[3] A spokes council is an assembly of affinity groups working by consensus (Graeber 2002: 70-71). Affinity groups are small assemblages of activists who know and trust each other. Usually, people travel together to events or actions, but affinity groups can also be formed on a more ad hoc basis around specific goals during an action. Within the affinity group, a decision is made about what kinds of activities the group will participate in and with what means. Moreover, the group members look after each other during and after confrontations with the police. Each group sends a delegate to spokes council meetings, which are held several times throughout an action or blockade to reach a consensus on tactical issues.

[4] The term 'Black bloc' denotes a particular tactic employed by left radical activists during demonstrations. This form of action, developed by German left radicals in the 1980s, involves demonstrators wearing black clothes and masks and forming a tight block by locking arms. In the activists' own words, this is done to avoid identification and arrests, and to give the demonstration a militant expression. The tactics used in the streets sometimes include vandalism and rioting (Katsiafikas 2006; Graeber 2009).

[5] During summit protests, activists rely on an organizational infrastructure that includes voluntary medical teams, trauma support units, and a legal team, which checks up on arrested activists, in addition to event planners, activists involved in the camp's organization (kitchen crews and clean-up crews), the press group and information team.

[6] A banlieue is a residential area on the outer edge of a city. In France, the term is used more frequently to describe areas of low-income apartments and social housing.

[7] The words 'feeling' and 'emotion' are often used interchangeably. Following Massumi (2002), I take feeling to be personal and biographical, whereas emotions are social (example.g. collective expressions of feelings or their social construction). Affects are pre-personal and non-conscious experiences of (bodily) intensity.

[8] Looking for politics in the body is not a new thing. Inspired by theories of feminism and philosophy, anthropologists have, over the past 40 years, interrogated nature-culture and mind-body dualities and pointed to the social and discursive production of sex, gender and bodies (see Lock 1993: 135; Povinelli 2006; Vilaça 2005; Wolputte 2004). According to Povinelli (2006), however, the muchneeded critique of the Western metaphysics of substance has led to the unfortunate abandonment of the material aspects of the body. Nonetheless, the attention that I give to the materiality of the body in the present context does not prevent it from being considered highly unstable (cf. Vilaça 2006).

[9] In a short article titled "Of Other Spaces," Michel Foucault (1986) describes the present epoch as one of the simultaneity of spaces. He talks of 'heterotopias' as real places, but also as counter-sites or effectively enacted utopias that have the property of standing in relation to all other spaces "in such a way as to suspect, neutralize or invert the set of relations that they happen to designate, mirror or reflect" (ibid.: 24). According to Foucault, it is a principle of the heterotopia that it juxtaposes several spaces in a single real place (the example being the Persian carpets that are reproductions of gardens, and gardens as the rug on to which the whole world is enacted). Moreover, heterotopias are linked to 
"slices in time," that is, to heterochronicity (ibid.: 26), which implies the emergence of several simultaneous modes of being in time. 